Article

\title{
Strategies for Post-COVID Cities: An Insight to Paris En Commun and Milano 2020
}

\author{
Carlo Pisano \\ Department of Architecture, University of Florence, 50100 Florence, Italy; carlo.pisano@unifi.it
}

Received: 17 May 2020; Accepted: 14 July 2020; Published: 22 July 2020

\begin{abstract}
In recent times, many infectious diseases have been spreading at an increasing scale and frequency. There is a common agreement in the literature that our cities should be prepared in the future to react promptly to epidemics, but the way in which this preparedness should be shaped is still an open question. This study aims to introduce a series of factors that should be taken into consideration in building a working framework to define and evaluate strategies for post-COVID cities. Through the use of the mutual learning methodology, this contribution draws on the concept of the epidemic prevention area (EPA) proposed by a research team at the School of Architecture, Southeast University (SEU) in China together with the UNESCO Chair in Cultural Resource Management, as an urban responding system to the COVID-19 epidemic, extracting its main factors and comparing them with two European post-COVID urban strategies: The Paris en Commun and Milano 2020. Research findings highlight that three factors-decentralization of facilities, hierarchization of the transport system and public services, and redundancy of public and semipublic functions-appeared to be particularly relevant in post-COVID cities, to promptly face future epidemic events, while improving their quality, equity, and resilience.
\end{abstract}

Keywords: post-COVID cities; urban clusters; polycentrism; epidemic prevention area (EPA); neighborhood planning; Paris en Commun; Milano 2020

\section{Introduction}

Over the last few decades, we recorded a growing interest in the relationship between urban planning and public health [1]. Although living environments in cities are generally healthier compared to rural settings-healthier housing conditions, better hygiene, and social services-urbanization is seen as one of the most relevant vehicles for infectious diseases, providing the environmental conditions for their fast spreading [2]. A great number of people living in a limited area can offer, in fact, the perfect conditions for different epidemics, thus creating a new challenge for both the local governments and the global community [2,3].

Many events in the history stress the strong connection between the rapid spread of infectious diseases and urban policies and plans. In 1800, for instance, after thousands of people died due to the viral disease of yellow fever, the future president Tomas Jefferson wrote to Philadelphia civic leader and physician Benjamin Rush that he hoped "yellow fever will discourage the growth of great cities in our nation and I view great cities as pestilential to the morals, the health and the liberties of man" [4].

Fifty years later, using a map of London urban area and the data regarding the urban water system, physician John Snow identified the cause of a cholera outbreak in London. His study showed that the areas supplied by a particular water pump were more affected by the disease than others. By closing the pump, they managed to control the epidemic. This accident, in addition to being a curious historical anecdote, proved the relation between spatial interactions and health and the relevance to integrate health-related factors in city planning and urban design [5]. In fact, some of the most iconic developments of the City, such as London's Metropolitan Board of Works and the 
mid-19th century sanitation systems, have been established, responding to public health calamities such as cholera outbreaks.

Snow's discoveries inspired the transformation of the water and waste systems of London, which were followed by other cities and a substantial improvement in overall public health around the world [6]. In New York, for instance, where tuberculosis was one of the principal causes of death in the early 1900s, social reformers like Jacob Riis documented the dirty, overcrowded conditions in dwellings, leading to regulations that finally fixed spatial requirements and required air shafts, windows, fire safety features, running water, and indoor toilets [7].

Another example can be dated to 1884, after a dreadful cholera epidemic affected the city of Naples, showing up the urgent need for a more decisive intervention on the historical urban grids via massive actions of land reclamation, the demolition of entire unhealthy areas, the construction of new infrastructures and social housing, and the planning of new districts of expansion. The government offered an extremely rapid response: On 15 January 1885, the Law for cleansing the city of Naples was enacted and in 1888, the Municipality adopted the Code of Hygiene and Public Health and the Società per il Risanamento di Napoli was established [8].

Even today, the 1918 Spanish Flu pandemic is considered one of the most devastating events in recorded human history. Considered to have started in North America in early 1918, the pandemic crossed the world in three different waves over a roughly 18-month period. Also, the lethality of the disease was remarkable, as it infected as much as 500 million people worldwide [9], before killing between 25 and 39 million people $[9,10]$. Before the development of medications, the treatment of pandemic diseases was environmental, influencing and even inspiring the austere forms of the new modern architecture, together with offering the chance to design and construct many new sanatorium and hospitals all over the world [11,12]. As the Swiss architect Le Corbusier declared, "A house is only habitable when it is full of light and air" [13]. Indeed, the set of principles related to architectural modernism - such as purity of form, strict geometries, modern materials, and a rejection of ornamentation-answered to the effects of war and disease that characterize the first half of the 20th century [11].

These few examples show how the reaction to epidemic diseases can shape cities, their physical layout, their management, but also the urban lifestyle. This interaction has brought to a progressive improvement of the health condition in cities, thus embodying health considerations in urban planning and design [5]. In recent years, many emerging infections have been occurring at a growing scale and frequency-i.e., Ebola, severe acute respiratory syndrome (SARS), avian and pandemic flu, Middle East respiratory syndrome (MERS), and the recently emerged coronavirus disease (COVID-19). Henceforth, the urban functional and spatial system should be designed accordingly, from the objective to meet the requirements of both daily life and of countering to the epidemic spread [14].

Entering 2020, with the sudden emergence of COVID-19, many cities highlighted a clear lack of the basic capacity responding to emergencies and disasters. In particular, European capitals were at the forefront of the fight against the pandemic both in relation to the pressure on the health sector as well as to the impact on economies [2]. COVID-19 first cases were confirmed in Rome already at the end of January and from the 13th of March 2020-when the number of new cases became greater than those in China-the World Health Organization began to consider Europe the active center of the COVID-19 pandemic [15]. From that moment, Milan, Madrid, Paris, and London rapidly became epicenters of the pandemic, showing similar difficulties addressing safety measures to limit the spread of the virus. Moreover, the European cultural economy was one of the hardly damaged sectors by the limitation of tourism due to lockdown [3,16], becoming a major objective in the EU's recovery plan [17].

In order to take required measures to manage the future epidemic, in the perspective of the loosening the lockdown measures, independent organizations such as World Health Organization (WHO) or International Council on Monuments and Sites (ICOMOS), but also national and local governments and municipalities, proposed a series of urban strategies meant to prepare our cities to react promptly to other similar epidemics. 
Although there is a common agreement in the literature that our cities should be prepared in the future to react promptly to other similar epidemics [18], the way in which this preparedness should be shaped is still an open question. This contribution aims to foster this open discussion by providing a series of factors that should be taken into consideration in building a working framework to define and evaluate strategies for post-COVID cities.

In the next section, we describe the main urban critical points to be implemented in response to COVID-19 epidemic spread. The Method section introduces the mutual learning methodology, through which this study draws on the concept of the epidemic prevention area (EPA) proposed by a research team at the School of Architecture, Southeast University (SEU) in China together with the UNESCO Chair in Cultural Resource Management and Sites-China and described in the material section.

In the following, we explore two post-COVID urban strategies, the Paris en Commun-started in occasion of the campaign for the Hidalgo re-election as Paris Mayor 2020 and relaunched as a post-COVID strategy-and Milano 2020, two of the firstly released post-pandemic urban policies for historical European capitals, heavily struck by the lock-down measures and characterized by extraordinary cultural and artistic values and a robust touristic based sector. In the discussion section, we analyze and compare the main characters of these strategies. Finally, we highlight a series of primary factors and criteria, which suggest a relevant base for the possible integration of post-COVID measures into existing cities.

\section{Motivation}

From the Ottawa Charter [19] and the strategies "Health in All Policies" [20], environment and living spaces have been considered crucial factors determining health conditions [19-21].

In particular, the strategy "Health in All Policies" [20] has clearly highlighted that health not only depends on providing health services and on individual lifestyles, but especially on environmental quality, working conditions and living standards, people's capabilities [22], community cohesion, and quality of public services of different kinds [21].

To reduce the vulnerability of cities regarding health issues therefore means to face a complex spectrum of topics, which characterized our urban living standards. In particular, some urban features can be identified as specific disruptive factors for pandemic spreading $[18,21,23]$. The most obvious one is the population density, but also social inequalities, which often result in poor quality housing, public environment, sanitation facilities, and insufficient freshwater or ventilation systems, all of which rise outbreak risks thus hindering outbreak prevention and control efforts. Other factors include the complexity of contact tracing, particularly for accidental contacts and potential encounters with wildlife through food markets or due to the expansion of urbanized areas into natural zones. Moreover, several scholars have highlighted a possible connection between poor air quality and COVID-19 deaths [24].

Following the indications set out in International Health Regulation (2005) [25], Public health preparedness and response (2018) [26], published by World Health Organization (WHO) [27], on 18 March 2020 a research team at the School of Architecture, Southeast University (SEU) in China together with the UNESCO Chair in Cultural Resource Management released a manual entitled "Urban Function-Spatial Response Strategy for the Epidemic" [14], in the following called Manual, which reports the COVID-19 outbreak in China, focus on emergency adjustment measures in some critical urban functional and spatial factors. They have been selected among the ones that are considered as the most relevant factors for the outbreak of pandemic diseases in cities. The aim is to ensure that, in the event of an epidemic situation, the urban system could obtain the highest possible response capacity [28].

Between the many, an excessive urban population density is seen as the main problem, particularly severe in developing countries in Asia, Africa, and South America. Quite often, infections either originate in cities, as was the case of COVID-19 in Wuhan region [29], or use cities to quickly spread, such as the outbreaks of SARS in 2003 and Zika virus disease in the Americas [28]. 
Rapid urbanization is seen as another factor since it may lead to violating natural habitats, increasing proximity to animals, providing possibilities for zoonotic infections. Among the 335 emerging infectious diseases recognized between 1940 and 2004, in fact, more than 60\% were of zoonotic origin [30].

Also, chaotic city roads and low levels of road hierarchy and facilities are highlighted as a criticality, leading to a high level of traffic congestion. "The urban transportation system is important to ensure the timely transportation of medical personnel, patients and various emergency materials when an epidemic occurs. It is the lifeline of the city during the epidemic period and its accessibility should be guaranteed first" [14].

The scarcity of large and small open spaces in the urban fabric and their unequal distribution is also mentioned as a factor in the disease spreading. "During the epidemic, the open space in city can be set as a temporary storage spot for materials and temporary patient receiving spots. Insufficient open space also means that the overall scale of the city's treatment is reduced, and the potential for coping with risks is relatively reduced" [14].

Inadequate medical facilities and low levels of public services are also seen as crucial factors that contribute to low capacity and lack of resources during pandemic crises. Particularly relevant is the uneven distribution of facilities since it could lead to the delay of the response time to the epidemic. Some large public services, such as sports centers, exposition halls, or schools can be temporarily adapted into medical facilities during crisis periods, to relieve the pressure of the distribution, treatment, and isolation of unusual quantities of patients. Certainly, these adaptation process needs to be planned ahead of time; without a forecast, the setting to put these measures into practice could need a considerable amount of time, thus allowing the epidemy to spread to the large scale before the system can take action [14].

In synthesis, from the perspective of urban planning and management, responding to the epidemic requires a system of integrated actions and provisions that could be coordinated only through a specific strategy that allow the cooperation between different departments and levels of administration, preparing the city to face future epidemic events. As a desirable side effect, this preparation could improve the general quality, equity, and resilience of cities. This strategy should be able to control excessive dense urban areas, reducing the possibility of transmission, while improving roads and services hierarchy to ensure the efficient transportation and supply of goods and medications. Another important factor is the provision of temporary uses in order to prepare extra space and facilities even in dense urban environments.

\section{Methods}

Adopting a qualitative comparison based on the mutual learning method [31,32], this study draws on the concept of the epidemic prevention area (EPA) as an urban responding system to the COVID-19 epidemic. From the EPA concept, this study extracts a series of factors intended to inform a potential working framework to define and evaluate strategies for post-COVID cities. These factors are then used to analyze two European post-COVID urban strategies: The Paris en Commun and Milano 2020.

The case studies have been chosen according to their relevance to the topic discussed. Paris and Milan are historical European capitals, heavily struck by the lock-down measures, characterized by extraordinary cultural and artistic values and a robust touristic based sector; moreover, they released two of the earliest post-pandemic urban strategies.

Due to the limited specific literature related to the post-pandemic urban strategies, the qualitative investigation was subject to an abductive interpretation [33], which refers directly to the circumstances of the investigation to highlight relationships and common characteristics between the case studies. In this method, the selected factors are intended as clusters around which the discussion will be framed [34]. 
Since no formal documents have been approved at the time of writing, the study will be based on the analysis of the discourses about post-COVID urban strategies, reconstructed through interviews with technicians or mayors $[35,36]$ and analyses of preliminary working documents $[37,38]$.

\section{Materials: The Epidemic Prevention Area Concept}

Planning cities in order to give an answer to epidemic threats require a dynamic approach able to face the continuous transformation of the external and internal conditions. Countries plan this transformation in different ways based on their interpretation of risks and international agreements such as the International Health Regulations (IHR) [25] or following the guidelines of World Health Organization (WHO) [27]. However, a shared fundamental approach to control the epidemic is to limit population movement in public places [14]. In this approach, the definition of the extent of this limit (i.e., to the home, condominium, neighborhood, district) is the crucial factor.

Based on this understanding and following the World Health Organization indications, the Urban Heritage Conservation and Sustainable Development Research Team, the School of Architecture, Southeast University (SEU), China, the SEU Key Laboratory of Urban and Architectural Heritage Conservation, the Ministry of Education, China, and the UNESCO Chair in Cultural Resource Management-proposes a model for organizing cities based on the concept of epidemic prevention area (EPA). An EPA is intended as an integrated urban functional and spatial responding system, meant to face to the epidemic thanks to the optimization of its present and local resources: Spaces, functions, and community [14]. Starting from this concept, a multi-level prevention system might be established for the whole city, in which a sequence of local clinics (or potential ones) are organized as a cluster based on the urban structure and population distribution.

When the epidemic reaches the city level, it is necessary to link multiple district-level EPA in the city to play a cluster role. For this reason, it is necessary to establish an effective emergency transportation system and designate some special places to accommodate suspected and infected people. If hospitals and clinics are inadequate, some public facilities such as parks, squares, sports fields, and schools need to be requisitioned as temporary points or mobile hospitals for patients. Therefore, an EPA cluster is a temporary adjustment of city management in emergency situations meant to concentrate and vigorously improve medical standards, maintaining, as much as possible, normal community life.

According to the Manual [14], the organization of cities in semiautonomous clusters offers several qualities in respond to epidemic spreading. On one hand, it could be possible to provide a clear hierarchically organized sanitary network with city-level hospitals and secondary hospitals/clinics more related to the district and community. On the other hand, the "life supporting system" of the city could be organized in order to allow people to be able to get the goods and facilities they need within the minimum distance from their houses, thus limiting the interaction with the other sectors of the population.

Therefore, by downsizing cities through EPA, both sanitary and life-supporting networks could be arranged to limit connections at the city scale. Obviously, keeping a strong connection between EPAs needs special care in order to distribute goods and medical services where they are mostly required. In this way, during the epidemic, some capillary road networks in the EPA should be closed to reduce people movements, while at the same time, leaving the main road network unobstructed, so that all kinds of materials can be smoothly reciprocally exchanged.

The EPA's clusters are proposed as emergency response, to be applied to existing urban conditions in time of epidemic crisis (Figure 1). There is, however, a common agreement in the literature that our cities should be prepared in the future to react promptly to other similar epidemics $[18,26]$. For this reason, the EPA concept could also become the starting point to develop a working framework for future urban transformation and reorganization. In particular, from the EPA concept is possible to draw on specific series of urban factors, which could be used to define and evaluate strategies for post-COVID cities: 
1. Decentralization of facilities. As opposed to extreme concentration and centralization of facilities, population, and poles of attractions, decentralization processes include both a redistribution of functions and power to lower government system, as well as policies to relocate public functions within the cities [39] in order to balance the differences between districts. The local dimension, stressed by the EPA concept, represents the fundamental property to reduce the response time, improving the efficiency of medical treatment, saving operating costs, and obtaining public support [14].

2. Hierarchization of the transport system and public services. The hierarchical definition of a street pattern and services provision implements the efficient organization of the medical and life support systems. Walking or bike distance accessibility to all basic facilities is a prerequisite to avoid excessive movement of people in the main road network.

3. Redundancy of public and semipublic functions. Often connected to sustainable and resilient urban forms [40], the concept of redundancy—frequently despised because intended as the opposite of optimization and efficiency-involves the duplication of critical components or functions of a system with the intention of increasing reliability.

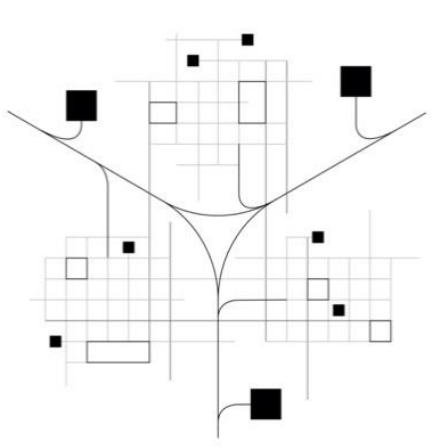

(a)

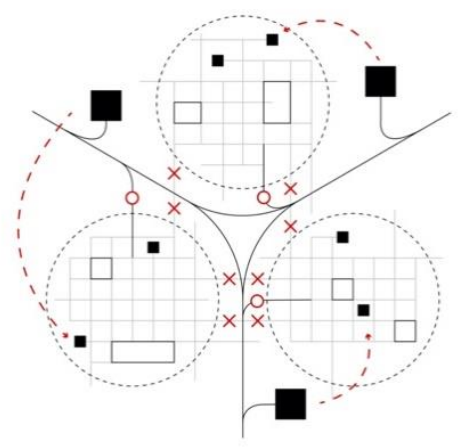

(b)

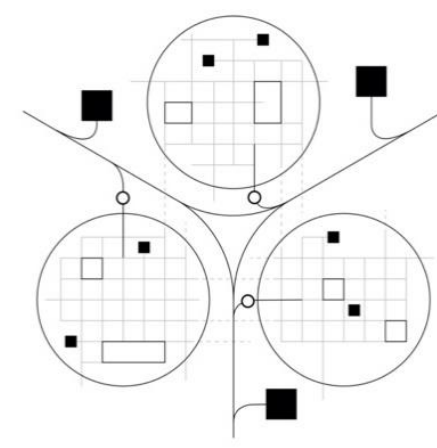

(c)

Figure 1. (a) Conceptual urban system before the pandemic spread: The highway system ensure accessibility to the different districts; the districts are connected between each other through secondary roads; health facilities (large and small squares) are mainly not specialized; (b) during pandemic spread, the epidemic prevention area (EPA) system is established: The main accesses of the districts are controlled; secondary connections between districts are not allowed; a clear hierarchy between health facilities is established; (c) both sanitary and life supporting networks could be arranged to limit connections at the city scale. Source: Author derived from the examples presented in the "Urban Function-Spatial Response Strategy for the Epidemic-A Concise Manual on Urban Emergency Management" [14] in particular from the case study of Shenzhen (pp. 17-19).

\section{Results}

As stated before, to promptly and effectively face an epidemic spreading, cities should become more polycentric, offering the possibility to be divided into semiautonomous clusters where the medical and life support systems are strictly connected from the urban to the community level as a whole. The urban model implied in the EPAs concept could be manifested via three factors-decentralization of facilities, hierarchization of the transport system and public services, and redundancy of public and semipublic functions.

From the perspective of urban history, polycentrism represented a reliable alternative to the enormous growth of the post-industrial megalopolis, pursued by several authors and urban plans in the recent past. From the Anglo-Saxon currents of thought, structured around the concepts of garden city and suburban neighborhood at the beginning of the 20th century, many methodological and intervention hypotheses have identified the neighborhood as the basic unit in which it is possible 
to guarantee social control [41]. This line of thought was recently updated by the leading thinkers of the New Urbanism movement [42,43].

In the form of concepts such as neighborhood units or, more recently, the urban degrowth [44] or hyper proximity [45], the polycentrism has left many important traces both in terms of images and readings, and of operational tools for the urbanized territory project based on the exaltation of the collective dimension of complex social structures [46].

Following this line of thought, adapted to the context of post-COVID, the recent strategies of Paris en Commun and Milano 2020 offer two examples of early reaction plans to epidemic spreading.

\subsection{Paris En Commun}

Since 2014, the year of the first election of Mayor Hidalgo, Paris went through a series of policies that banned the most polluting vehicles from entry to the city, freed the quayside of the Seine from cars, and regained the space of the streets for more trees and pedestrian space. This process of pedestrianization of the city was fostered during the Hidalgo campaign for re-election 2020, Paris en Commun. This campaign manifesto has been relaunched as a post-COVID strategy, introducing the concept of a "15 min city", in which citizens' basic needs, such as work, shopping, health, or culture, should be available within $15 \mathrm{~min}$ of their home (Figure 2).

Applied to the city level, the creation of 15-min clusters would need a sort of deconstruction of the city, improving diversity and lowering the unbalanced distribution of facilities between districts. As Hidalgo adviser Moreno states "there are six things that make an urbanite happy: dwelling in dignity, working in proper conditions, [being able to gain] provisions, well-being, education and leisure. To improve quality of life, you need to reduce the access radius for these functions" [47]. That commitment to fetching all life's essentials to each neighborhood means creating a more carefully integrated urban fabric, where stores mix with homes, bars mix with health centers, and schools with office buildings [48].

The functional mix challenges especially the car-centric suburban areas shaped by large schools, blind box retail strips, and massive industrial and office parks, all separated from each other and connected by networks of roads and parking infrastructure [49]. The notion of "hyper proximity" introduced by Moreno to express the qualities of the 15-min city seeks to bring back to the city level some of these uses [45] inserting them into a new social logic [50].

Paris en Commun's strategy drafts some features of the future hyperlocal city. More road space would be dedicated to bikes and pedestrians, giving the public and semi-public spaces numerous uses, such as daytime schoolyards could become nighttime sports facilities and several functions outlets would be encouraged, such as smaller stores, bookstores, and grocery stores [51]. In $15 \mathrm{~min}$, every citizen would be able to reach his doctor (and ideally a medical center) and sports facilities.

The most evident measure proposed is the extension of the urban bike network, that would connect the city center to the suburbs. This network was already under examination before the COVID pandemic, but its design has been accelerated and proposed as an emergency measure in order to allow more people to commute using the bike across Greater Paris. For the near future, for instance, Rue de Rivoli will be entirely dedicated to bikes and pedestrians, and only public transport and taxis will be able to travel using a narrow central strip of the road [24]. 

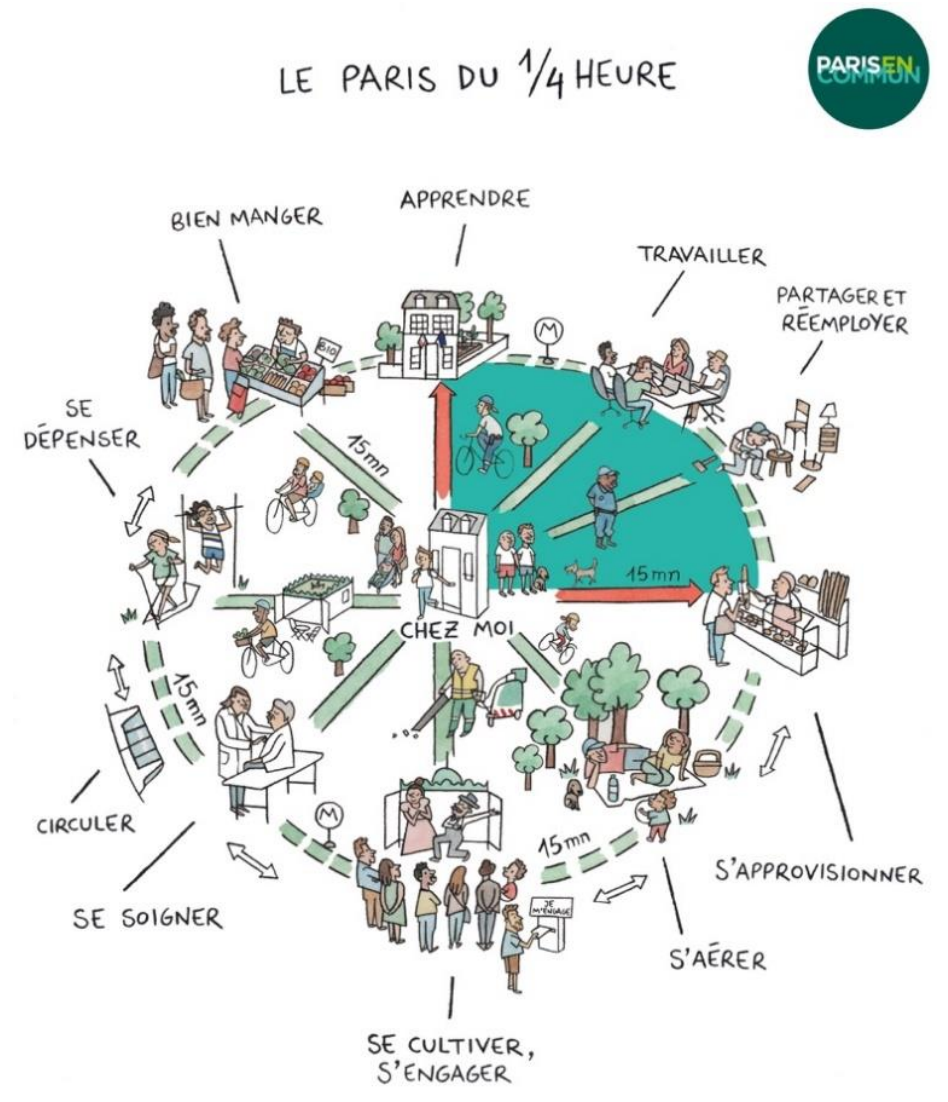

Mic Ėं

Figure 2. Paris en Commun's 15-min city concept. From the top, clockwise, the headings read: Learn, Work, Share and Re-Use, Get Supplies, Take the Air, Self-Develop and Connect, Look After Yourself, Get Around, Spend, and Eat Well. Source: Paris en Commun [37,48].

\subsection{Milano 2020}

Milano 2020 is the adaptation strategy proposed by the city of Milan for the restart of the so-called phase 2, after the lockdown period. The document was released the 24th of April 2020 as a draft, open to observations and contributions through an online participatory process, which started the 27th of April, to ensure its dynamic updating in the face of ever-changing scenarios.

Like many other European cities, Milan reacted to the COVID-19 crisis through the revaluation of the use of private transportation, which, due to limitation imposed by the social distance to public transport, could become the most popular commuting mode in the early post-COVID period [52]. With the $55 \%$ of the population using daily public transport before the pandemic, the city of Milan-like many other European cities-cannot provide enough space for cars or parking lots to switch to private vehicles [53].

To face these problems but also to guide the post-COVID recovery, the Municipality of Milan elaborated the Milano 2020 strategy [38] for adaptation to a "new ordinary", with the end of the lockdown phase, namely Phase 1 . This document implies "the preparation in view of any future critical situations that could occur and, therefore, set up a pre lockdown containment phase and foresee the risk of new lockdowns, taking advantage of the experience lived in Phase 1" [38].

Based on five strategic lines-governance, rights, and inclusion; economies, resources, and values; work; times, spaces, and services; and sustainability—the vision of Milano 2020 is willing to both return as quickly as possible to the previous levels, which will be very difficult in the context of prolonged limitations, but also to promote a strong environmental change, placing at the center of all actions the 
theme of equity, the attention to old and new episodes of fragility and poverty, and a new concept of health protection, that goes beyond to the mere treatment and prevention of diseases.

Mobility is at the center of the strategy and one of the most challenging changes. The very efficient public transport system of the city will undergo important capacity limitations. The persistence of the smart working as a privileged operating mode whenever is possible and the deferral of the rush hours have been identified as a way to counteract the problem, together with the increase the non-polluting transport system (feet, bikes, light mobility) but also a general (re) organization of the times of the city.

Although the role played by bus, trams, and metro in spreading the disease remains controversial, it is clear that public transport, if overcrowded, could become a hot spot for transmission. Accordingly, says the mayor Sala [35], the city plans to maintain its metro system's capacity at less than two-thirds of its pre-pandemic activity. Instead of the previous 1.4 million average trips per day, it will accommodate a maximum daily ridership of 400,000 .

Therefore, also the city of Milan proposes to invest in cycling and walking (Figure 3). During the summer of 2020, the urban core will be partly adapted to transform over $35 \mathrm{~km}$ of road space into bike lanes and pedestrian paths and in addition, the vehicles allowed into the center must respect a new reduced $30 \mathrm{~km}$ per hour speed limit. The aim is to make traffic more fluid and give pedestrians more space to spread out safely [53].

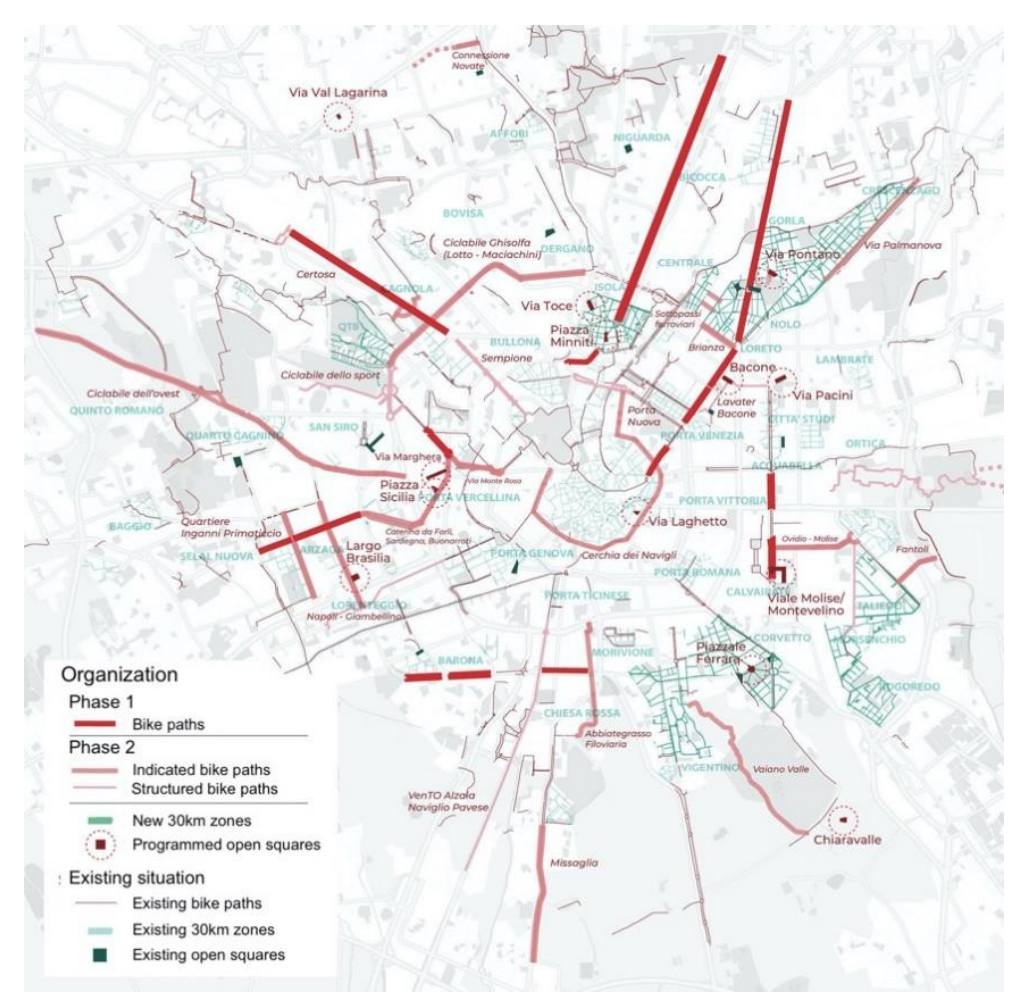

Figure 3. Maps of the interventions foreseen in the post-COVID strategy. Source: Milano 2020 [54].

Similarly to the Paris En Commun strategy, also Milano 2020 stresses the importance to rediscover the size of the neighborhood (the city within a 15-min walk), making sure that every citizen has access to almost all services within a walking distance. This concept will involve the strengthening of public services with attention to proximity, ensuring access within a 15-min walk, balancing the differences between neighborhoods, enhancing specificities, and trying to reduce inter-district travel. Accordingly, the Municipality will cooperate with the Lombardy Region to create local medical services, starting from popular neighborhoods, with high population density and characterized by an older population. 


\section{Discussions}

The factors drawn from the EPA concept-decentralization of facilities, hierarchization of the transport system and public services, and redundancy of public and semipublic functions-represent the starting point to develop a working framework for adapting existing urban conditions in the time of epidemic crisis, but they could also become a guiding principle for future urban transformation and reorganization. Through these factors, the post-COVID strategies of Paris and Milan could be analyzed in order to verify and question their adherence to the adaptation guidelines promulgated in the Manual, helping the development of a potential working framework.

1. Decentralization of facilities. The local dimension stressed by the EPA concept represents the fundamental property to reduce the response time, improving the efficiency of medical treatment [14], and, at the same time, focusing the public support at the scale of the neighborhood. The strategy proposed by the Mayor of Paris "15 min city" [47], as well as the concept of "hyper proximity" suggested by Moreno [45], seem to follow exactly this path. As Mayor Hidalgo suggested, the general aim of the strategy is to "deconstruct" the city of Paris so every neighborhood has a mix of stores, homes, office buildings, and other uses, and residents can satisfy most of their needs within a 15-min walk [7]. Similarly, also Milano 2020 stresses the importance to rediscover the size of the neighborhood, making sure that every citizen has access to almost all services within a walking distance. The decentralization processes will include the creation of local medical services, programmed together with the Lombardy Region, in order to equilibrate differences between districts. As visible in the plan of the foreseen interventions (Figure 4), a series of new open squares will become the starting points of this renovation.

2. Hierarchization of the transport system and public services. Before COVID-19, many European cities were planning a reduction of the urban space dedicated to cars and a parallel improvement of their cycling infrastructure and the enlargement of sidewalks. Both the Paris and Milan strategies particularly stress pro-pedestrian policies as efficient ways to build a livable post-pandemic urban future. In particular, the municipality of Milan organizes this strategy through layered solutions, from the main public transport system-metro, tram, and bus lines-which should lower their capacity to avoid risk for transmission, to the improvement of $35 \mathrm{~km}$ of bike lanes. The strategy also involves a general (re)organization of the times of the city to redraw city's work, school, and daily lifetime patterns, avoiding congestions during peak hours. In Paris, a hierarchical distribution of facilities is encouraged, with a particular focus on the smaller retail outlets, bookstores, grocery stores, and workshops. In their vision, every citizen should be able to reach a doctor or a sports facility within a limited amount of time. Stressing the local and small dimension will counterbalance the existing provision of large-scale facilities and services, together with providing a strongly integrated hierarchical system of amenities.

3. Redundancy of public and semipublic functions. Both the Paris and Milan strategies rely on the principle that the urban structure should be flexible in order to meet the needs of both ordinary and extraordinary conditions. This could affect the regular life citizens, but, as Milano 2020 clearly states, every future strategy should not only consider the restart of the so-called phase 2 but should also imply the preparation in view of any future critical situation that can occur in the future. Due to the necessity to organize a diffused and evenly distributed network of facility, services, and amenities, some duplication or inefficiencies are unavoidable; however, it is essential to invest in the preparation of a redundant provision of public amenities, from first aid systems to social facilities. In this regard, multipurpose uses of flexible public spaces and buildings could help reducing inefficiencies (Figure 4). For this reason, Paris en Commun encourages flexibility and multiple uses of public and semipublic spaces as a possible strategy to face future needs by implementing the quality of everyday life. In the same direction, Milano 2020 fosters a system of dual uses infrastructures with temporary reuse of infrastructure and public buildings to make a significant contribution to emergency management. As an example, with the project "Milan 
school oasis", the Municipality allocates school buildings and green areas, in the summer months in particular, to educational accompaniment activities.

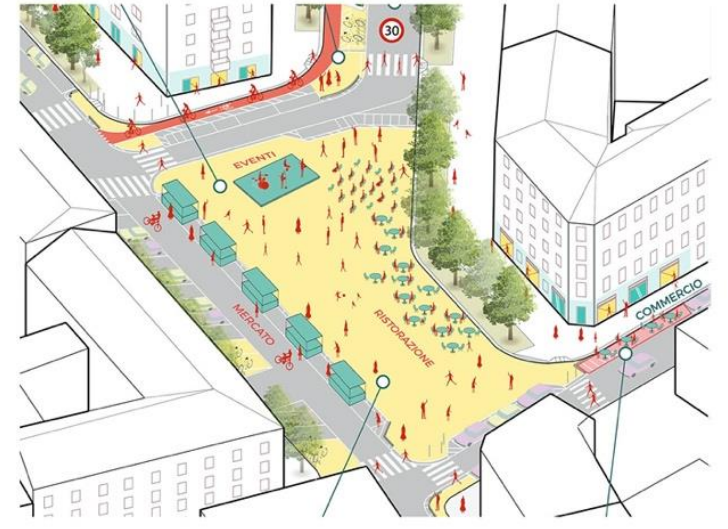

(a)

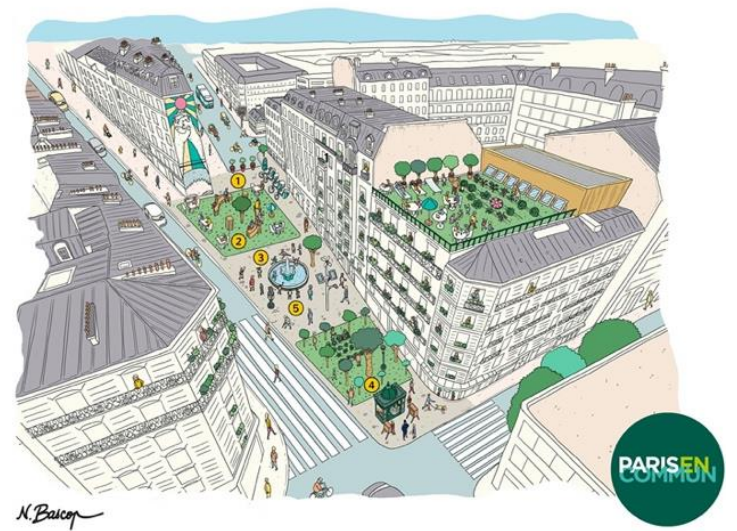

(b)

Figure 4. (a) Image of the transformation of the Minniti square in Isola, with the creation of larger public and semi-public spaces and $30 \mathrm{~km}$ zones Source: Milano 2020 [54]; (b) image of a possible intervention foreseen by the Paris en Commun strategy. New trees, green roofs and balconies, and a fountain would help mitigate the heat island effect and make the area a more pleasant place to linger. Meanwhile, the crossing space has ballooned in size, providing greater priority for pedestrians. Source: Nicolas Bascop/Paris en Commun [48].

Two aspects seem particularly interesting to be discussed regarding the possible implementation of a working framework to define and evaluate strategies for post-COVID cities: On one side, the potential improvements that pandemic preparation could provide for other urban aspects, such as livability, sustainability, or resilience; on the other, the way in which the three factors, drawn from the epidemic prevention area concept, can be used to evaluate other strategies in other contexts.

For the first point, although it has not been explicitly stated in the documents underlying Paris en Commun and Milano 2020 strategies, it is clear that some of the factors of immediate pandemic responses, namely the "15 min city", "hyper proximity", or green city policies, overlap with the EPA concept described in the material section. Moreover, these strategies link the preparation of cities to future epidemic calamities with plans to generally improve the daily life of the urban dwellers [55].

In particular, the attention paid to the scale of the neighborhood, underlined by the 15-min city policy, reduces the urban movements, limiting unjustified traffic and facilitating a fairer distribution of services. As well as the secondary connections between districts could be transformed, at least partially, to bike and pedestrian routes and more flexible spaces could be implemented to allow different uses during normal or crisis periods (Figure 5).

For these reasons, a strong combination of goals, approaches, and concepts could inform future post-pandemic urban strategies, in which the health issues are just one of the many factors to be included.

On the other side, the three factors extracted from the EPA concept are just the first canvas of a potential working framework to be implemented with more detailed and site-specific indications, related to health services [19,20], environmental qualities, or people capabilities [22]. The implications of the three factors are not, however, neutral in relation to the contemporary urbanistic theories and practices. The hierarchization of street patterns and service distribution, for instance, is seen as antagonistic, to certain extend, to the concept of porosity [56], permeability [57], and connectivity [58] which characterize the rhetoric behind many contemporary plans. These concepts could be called into question in light of the events of the last months. 


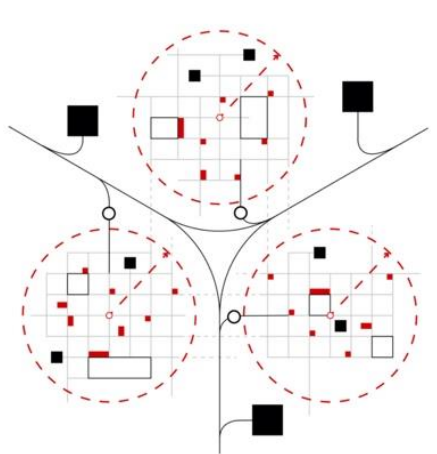

(a)

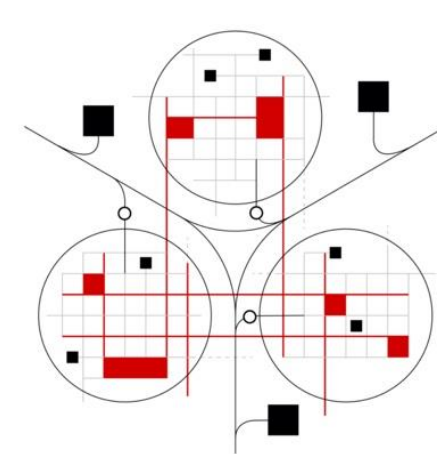

(b)

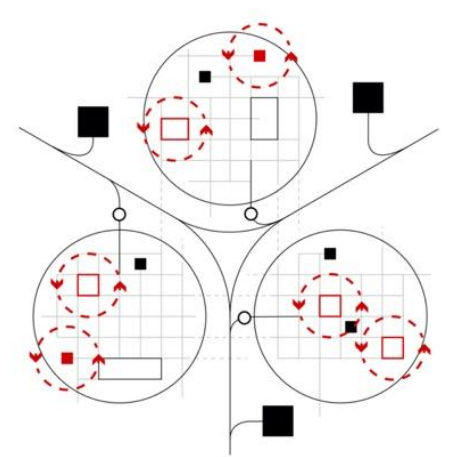

(c)

Figure 5. Conceptual schemes, which highlight the links between the EPA concept and the 15-min city policy in relation to: (a) A fairer distribution of services; (b) the partial transformation of secondary connections between districts in bike and pedestrian routes; (c) the implementation of more flexible public spaces and buildings to allow different uses during normal or crisis periods. Source: Author.

\section{Conclusions}

From a statistical perspective, any calamity—such as river overflows, earthquakes, or epidemic spreading-is supposed to be a rare event with small probability to occur. However, if cities do not set efficient measures to prevent such "small probability", when these calamities occur, their results cannot be controlled. Therefore, cities must take effective, scientifically driven, proportional actions to improve their capacity to answer to exceptional "small-probability" events.

There is a common agreement in the literature that our cities should be prepared in the future to react promptly to epidemics. Some strategic documents have been developed by the main capitals worldwide and many of them are under preparation at the moment, but the way in which this preparedness should be shaped is still an open question. Applying a Mutual Learning methodology, this contribution has compared the main factors extracted from the Epidemic Prevention Area (EPA) concept-introduce in the "Urban Function-Spatial Response Strategy for the Epidemic", a concise manual elaborated by a research team at the School of Architecture, Southeast University (SEU) in China together with the UNESCO Chair in Cultural Resource Management-with two European post-COVID urban strategies, the Paris en Commun and Milano 2020.

From this study, three factors appeared to be particularly relevant in the definition of a potential working framework to define and evaluate strategies for post-COVID cities, while improving their quality, equity, and resilience: Decentralization of facilities, hierarchization of the transport system and public services, and redundancy of public and semipublic functions. In both Paris en Commun and Milano 2020 strategies, these three factors could be traced subsumed by the principle of the "15-min city", which proposes a city composed by protected and controllable communities, served by a decentralized system of local facilities and amenities. The reduction of the urban space dedicated to cars and a parallel improvement of cycling and pedestrian infrastructure, together with the flexible use of public and semipublic spaces and amenities, are important policies proposed by Paris and Milan.

The study emphasizes two aspects that can guide the future researches on the field of post-pandemic urban strategies. On one side, the study highlights the necessity to strongly combine goals, approaches, and concepts, related, for instance, to the livability, sustainability, or resilience of cities, into a comprehensive strategy where the health issues are just one of the many factors to be included. On the other side, the description of the case studies shows that the implications of the three factors, drawn from the EPA concept, are not neutral concerning the contemporary urbanistic theories and practices, requiring deep reflections about topics such as porosity, permeability or connectivity.

Further researches are needed to implement a coherent and complete working framework for post-COVID cities. This article presented only a first insight into this topic, but many questions are still on the table, for instance, the definition of the dimension of the EPA clusters, their relation to 
the administrative urban subdivision, the type and the amount of vital services to be included, and also the necessity to clarify possible different local declination of this framework related to cultural, geographical, and economical aspects.

What is certain is that the plans to answer this specific epidemic situation should additionally prepare cities for future calamities, also contributing to improve the daily life of their citizens. Due to the "small" but still existing probability that events like COVID-19 will affect again our urban life, cities must prove to be able to respond to such unconventional events.

Funding: This research received no external funding.

Acknowledgments: The author would like to thank the many materials, data, papers, and reflections that were posted rapidly and openly during the lockdown period, from Institutions such as WHO, UNWTO, and Icomos, from cities and provinces such as Milan and Paris, but also by research centers and independent scholars worldwide.

Conflicts of Interest: The author declares no conflict of interest.

\section{References}

1. D'Alessandro, D.; Appolloni, L.; Capasso, L. Public health and urban planning: A powerful alliance to be enhanced in Italy. Ann. Ig. Med. Prev. E Comunita 2017, 29, 453-463. [CrossRef]

2. Neiderud, C.-J. How urbanization affects the epidemiology of emerging infectious diseases. Infect. Ecol. Epidemiol. 2015, 5, 27060. [CrossRef] [PubMed]

3. UNWTO \& Data Partners COVID-19-A Global Insight on Travel and Tourism Impacts. Available online: https://webunwto.s3.eu-west-1.amazonaws.com/s3fs-public/2020-03/21_4_Tourism_COVID19_Data_ Coalitionpptx.pdf (accessed on 30 April 2020).

4. Jefferson, T. From Thomas Jefferson to Benjamin Rush, 23 September 1800. Available online: http://founders. archives.gov/documents/Jefferson/01-32-02-0102 (accessed on 30 April 2020).

5. How to Mitigate the Impact of an Epidemic and Prevent the Spread of the Next Viral Disease: A Guide for Designers. Available online: https://www.gsd.harvard.edu/2020/03/how-to-mitigate-the-impact-of-anepidemic-and-prevent-the-spread-of-viral-diseases-a-guide-for-designers/ (accessed on 30 April 2020).

6. Vinten-Johansen, P.; Brody, H.; Paneth, N.; Rachman, S.; Rip, M.; Zuck, D. Cholera, Chloroform, and the Science of Medicine: A Life of John Snow; Oxford University Press: New York, NY, USA, 2003; ISBN 978-0-19-974788-7.

7. How Philly's Neighborhoods Can Help Us Understand Pandemics. Available online: https://whyy.org/ articles/how-phillys-neighborhoods-can-help-us-understand-pandemics/ (accessed on 30 April 2020).

8. Manzo, E. Il "Risanamento" di Napoli. Dal progetto urbano alla scala architettonica. Atti E Rassegna Tec. Della Soc. Degli Ing. E Degli Archit. Torino 2018, 151, 113-122.

9. Taubenberger, J.K.; Morens, D.M. 1918 Influenza: The Mother of All Pandemics. Emerg. Infect. Dis. 2006, 12, 15-22. [CrossRef] [PubMed]

10. Johnson, N.P.A.S.; Mueller, J. Updating the accounts: Global mortality of the 1918-1920 “Spanish" influenza pandemic. Bull. Hist. Med. 2002, 76, 105-115. [CrossRef] [PubMed]

11. Chang, V. Cholera Outbreaks and the 1918 Flu Transformed Architecture. The Coronavirus Will Do It Again. Available online: https://slate.com/business/2020/04/coronavirus-architecture-1918-flu-cholera-modernism. $\mathrm{html}$ (accessed on 5 May 2020).

12. Hatchett, R.J.; Mecher, C.E.; Lipsitch, M. Public health interventions and epidemic intensity during the 1918 influenza pandemic. Proc. Natl. Acad. Sci. USA 2007, 104, 7582-7587. [CrossRef] [PubMed]

13. Corbusier, L. Towards a New Architecture; Courier Corporation: North Chelmsford, MA, USA, 1986; ISBN 978-0-486-25023-6.

14. Urban Heritage Conservation and Sustainable Development Research Team; School of Architecture, Southeast University (SEU), China; SEU Key Laboratory of Urban and Architectural Heritage Conservation, Ministry of Education, China; UNESCO Chair in Cultural Resource Management. Urban Function-Spatial Response Strategy for the Epidemic - A Concise Manual on Urban Emergency Management; SEU Arch: Nanjing, China, 2020.

15. Fredericks, B. WHO Says Europe Is New Epicenter of Coronavirus Pandemic. Available online: https://nypost. com/2020/03/13/who-says-europe-is-new-epicenter-of-coronavirus-pandemic/ (accessed on 2 June 2020). 
16. World Tourism Organization (UNWTO); Organization of American States (OAS) (Eds.) Tourism and the Sustainable Development Goals—Good Practices in the Americas; World Tourism Organization (UNWTO): Madrid, Spain, 2018; ISBN 978-92-844-1968-5.

17. COVID-19: Save European culture and values, MEPs tell Commission | Attualità | Parlamento europeo. Available online: https:/www.europarl.europa.eu/news/it/press-room/20200502IPR78302/covid-19-saveeuropean-culture-and-values-meps-tell-commission (accessed on 2 June 2020).

18. Lee, V.J.; Aguilera, X.; Heymann, D.; Wilder-Smith, A.; Lee, V.J.; Aguilera, X.; Heymann, D.L.; Wilder-Smith, A.; Bausch, D.G.; Briand, S.; et al. Preparedness for emerging epidemic threats: A Lancet Infectious Diseases Commission. Lancet Infect. Dis. 2020, 20, 17-19. [CrossRef]

19. WHO | The Ottawa Charter for Health Promotion. Available online: http://www.who.int/healthpromotion/ conferences/previous/ottawa/en/ (accessed on 31 May 2020).

20. WHO | Health in All Policies: Framework for Country Action. Available online: http://www.who.int/ healthpromotion/frameworkforcountryaction/en/ (accessed on 31 May 2020).

21. D'Alessandro, D.; Arletti, S.; Azara, A.; Buffoli, M.; Capasso, M. Strategies for Disease Prevention and Health Promotion in Urban Areas: The Erice 50 Charter. Ann. Ig. Med. Prev. E Comunità 2017, 29, 481-493. [CrossRef]

22. Blečić, I.; Cecchini, A.; Talu, V. The Capability Approach in Urban Quality of Life and Urban Policies: Towards a Conceptual Framework. In City Project and Public Space; Serreli, S., Ed.; Urban and Landscape Perspectives; Springer Netherlands: Dordrecht, The Netherlands, 2013; pp. 269-288, ISBN 978-94-007-6037-0.

23. The Urban Now: Preparing Cities for Epidemics: Lessons from the COVID19 Outbreak. Available online: https://www.ijurr.org/the-urban-now/preparing-cities-for-epidemics/ (accessed on 31 May 2020).

24. O'Sullivan, F. Paris Has a Plan to Keep Cars Out After Lockdown. Available online: https://www.citylab. com/transportation/2020/04/paris-cars-air-pollution-health-public-transit-bike-lanes/610861/ (accessed on 1 May 2020).

25. Statement on the Meeting of the International Health Regulations (2005) Emergency Committee for Ebola Virus Disease in the Democratic Republic of the Congo on 18 October 2019. Available online: https://www. who.int/news-room/detail/18-10-2019-statement-on-the-meeting-of-the-international-health-regulations(2005)-emergency-committee-for-ebola-virus-disease-in-the-democratic-republic-of-the-congo (accessed on 30 April 2020).

26. Public Health Emergency Preparedness and Response Capabilities. Available online: https://www.cdc.gov/ cpr/readiness/capabilities-change.htm (accessed on 30 April 2020).

27. World Health OrganizationRegional Office for Europe Moving around during the COVID-19 outbreak. Available online: https://who.canto.global/pdfviewer/viewer/viewer.html?v=coronavirus\& portalType $=\mathrm{v} \% 2$ Fcoronavirus\&share $=$ share $\% 2$ Calbum $\% 2 C M F S Q 0 \&$ column $=$ document\&id $=$ m19hqak5812rt8h4v97hdadk5b\&suffix=pdf (accessed on 16 May 2020).

28. Lee, V.J.; Ho, M.; Kai, C.W.; Aguilera, X.; Heymann, D.; Wilder-Smith, A. Epidemic preparedness in urban settings: New challenges and opportunities. Lancet Infect. Dis. 2020, 20, 527-529. [CrossRef]

29. Li, Q.; Guan, X.; Wu, P.; Wang, X.; Zhou, L.; Tong, Y.; Ren, R.; Leung, K.S.M.; Lau, E.H.Y.; Wong, J.Y.; et al. Early Transmission Dynamics in Wuhan, China, of Novel Coronavirus-Infected Pneumonia. N. Engl. J. Med. 2020, 382, 1199-1207. [CrossRef] [PubMed]

30. Jones, K.E.; Patel, N.G.; Levy, M.A.; Storeygard, A.; Balk, D.; Gittleman, J.L.; Daszak, P. Global trends in emerging infectious diseases. Nature 2008, 451, 990-993. [CrossRef] [PubMed]

31. Mutual Learning - PSF | RIO - H2020 PSF. Available online: https://rio.jrc.ec.europa.eu/policy-supportfacility/mutual-learning (accessed on 18 June 2020).

32. Vilsmaier, U.; Engbers, M.; Luthardt, P.; Maas-Deipenbrock, R.M.; Wunderlich, S.; Scholz, R.W. Case-based Mutual Learning Sessions: Knowledge integration and transfer in transdisciplinary processes. Sustain. Sci. 2015, 10, 563-580. [CrossRef]

33. Peirce, C.S. Philosophical Writings of Peirce; Courier Corporation: North Chelmsford, MA, USA, 1955; ISBN 978-0-486-20217-4.

34. Schöbel, S. Qualitative Research as a Perspective for Urban Open Space Planning. J. Landsc. Archit. 2006, 1, 38-47. [CrossRef] 
35. Giannattasio, M. Sala: «Milano avrà nuovi orari: Doppi turni per le scuole e negozi aperti la sera». Available online: https://milano.corriere.it/notizie/cronaca/20_aprile_20/04-politico-t1ewqeqwecorriere-web-milano2a62583a-826d-11ea-afba-f0dcf1bf9a9f.shtml (accessed on 1 May 2020).

36. Willsher, K. Paris Mayor Unveils "15-Minute City" Plan in Re-Election Campaign. Available online: https://www.theguardian.com/world/2020/feb/07/paris-mayor-unveils-15-minute-city-plan-in-reelection-campaign (accessed on 3 May 2020).

37. Anne Hidalgo Paris en Commun. Available online: https://annehidalgo2020.com/ (accessed on 1 May 2020).

38. Comune di Milano Milano 2020 - Strategia di adattamento. Documento aperto al contributo della città. Available online: https://www.comune.milano.it/aree-tematiche/partecipazione/milano-2020 (accessed on 2 May 2020).

39. von Braun, J. Urbanization and Decentralization: The Changing Urban-Rural Linkages and Opportunities of Decentralization of Services; ERSA conference papers; European Regional Science Association: St. Petersburg, Russia, 2014.

40. UN-Habitat; UNDP (Eds.) The Impact of Decentralization and Urban Governance on Building Inclusive and Resilient Cities; Asia-Pacific Urbanization and Climate Change Issue: Bangkok, Thailand, 2014.

41. Perry, A.C. Housing For The Machine Age; Russel Sage Foundation: New York, NY, USA, 1939.

42. Haas, T. New Urbanism and Beyond: Designing Cities for the Future, 1st ed.; Rizzoli Intl Pubns: New York, NY, USA, 2008; ISBN 978-0-8478-3111-1.

43. Mouzon, S. Architectural Elements: Traditional Construction Details, 1st ed.; McGraw-Hill Professional: New York, NY, USA, 2000; ISBN 978-0-07-137427-9.

44. Wächter, P. The Impacts of Spatial Planning on Degrowth. Sustainability 2013, 5, 1067-1079. [CrossRef]

45. Commander le Hors-Série Alliancy, le mag. Available online: https://www.alliancy.fr/commander-alliancyle-mag-hors-serie-vivre-et-travailler-en-2030-version-papier (accessed on 2 May 2020).

46. Pisano, C. L'uso di Spatial Concept nel progetto d'area vasta. Tre genealogie a confronto. CRIOS 2019, 18, 21-36. [CrossRef]

47. Belaïch, C. Municipales à Paris: «Il faut déconstruire la ville segmentée». Available online: https://www. liberation.fr/france/2020/01/20/il-faut-deconstruire-la-ville-segmentee_1774182 (accessed on 2 May 2020).

48. O'Sullivan, F. It's Time for the '15-Minute City'. Available online: https://www.citylab.com/environment/ 2020/02/paris-election-anne-hidalgo-city-planning-walks-stores-parks/606325/ (accessed on 30 April 2020).

49. Pisano, C. Patchwork Metropolis. Progetto di città contemporanea; Research; Lettera Ventidue edizioni: Siracusa, Italy, 2018.

50. Sennet, R. Costruire e abitare. Etica per la città; Feltrinelli: Milano, Italy, 2018; ISBN 978-88-07-10535-7.

51. Marx, P. Bring on the 15-Minute City! Available online: https://radicalurbanist.substack.com/p/bring-on-the15-minute-city (accessed on 9 May 2020).

52. Ricci, G. Post-lockdown urban policies as an opportunity for radical transformations. Available online: https:/www.domusweb.it/en/architecture/gallery/2020/05/14/post-lockdown-urban-policies-an-opportunity-forradical-transformations-tactical-urbanism-mobility-bicycles.html (accessed on 16 May 2020).

53. O'Sullivan, F. Europe's Cities Are Making Less Room for Cars after Coronavirus. Available online: https://www.citylab.com/transportation/2020/04/coronavirus-reopen-cities-public-transit-car-freebike-milan/610360/ (accessed on 1 May 2020).

54. Milano | Urbanistica: "Piazze Aperte", la rivoluzione nei quartieri dopo Covid19. Available online: https://blog.urbanfile.org/2020/05/01/milano-urbanistica-piazze-aperte-la-rivoluzione-nei-quartieridopo-covid19/ (accessed on 9 May 2020).

55. Gehl, J.; Rogers, R. Cities for People, 1st ed.; Island Pr: Washington, DC, USA, 2010; ISBN 978-1-59726-573-7.

56. Secchi, B.; Viganò, P. La ville poreuse. Un projet pour le grand Paris et la métropole de l'après-kyoto, 1st ed.; METISPRESSES: Geneva, Switzerland, 2011; ISBN 978-2-940406-56-2.

57. Alonso de Andrade, P.; Berghauser Pont, M.; Amorim, L. Development of a Measure of Permeability between Private and Public Space. Urban Sci. 2018, 2, 87. [CrossRef]

58. Rusche, K.; Reimer, M.; Stichmann, R. Mapping and Assessing Green Infrastructure Connectivity in European City Regions. Sustainability 2019, 11, 1819. [CrossRef]

(C) 2020 by the author. Licensee MDPI, Basel, Switzerland. This article is an open access article distributed under the terms and conditions of the Creative Commons Attribution (CC BY) license (http://creativecommons.org/licenses/by/4.0/). 